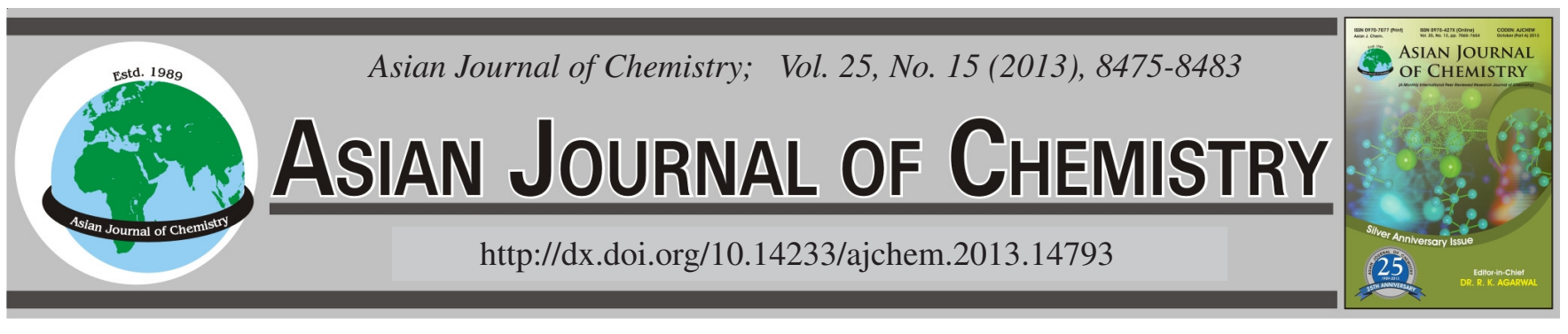

\title{
Cationized Natural Dyeing of Cotton Fabrics with Corn Poppy (Papaver rhoeas) and Investigation of Antibacterial Activity
}

\author{
Gorkem GediK ${ }^{1}$, Arzu Yavas ${ }^{1}$, Ozan Avinc $^{1, *}$ and ÖMer Simser $^{2}$
}

${ }^{1}$ Department of Textile Engineering, Pamukkale University, 20070 Denizli, Turkey

${ }^{2}$ Department of Food Engineering, Pamukkale University, 20070 Denizli, Turkey

*Corresponding author: E-mail: oavinc@ @au.edu.tr

(Received: 7 November 2012;

Accepted: 24 August 2013)

AJC-13977

\begin{abstract}
In this study, cotton fabrics were dyed with Papaver rhoeas flowers (petals) in company with four different mordant chemicals via premordanting method. The effect of cationizing was investigated. Colorimetric properties, colour fastness (wash, alkali and acid perspiration, wet and dry rub and light fastness) values and antibacterial activity were determined after different process sequence combinations of cationizing, mordanting and dyeing. Different shades of green, brown, lead and tan colours were obtained on cotton fiber dyed with papaver rhoeas flowers. Cationizing process increased the colour yield on both un-mordanted and mordanted samples. Sequential application of cationizing then dyeing resulted in significantly higher colour yield value than simultaneous application of cationizing and dyeing. The application of a cationizing agent together with a mordant material at the pre-mordanting step then dyeing caused the highest colour values on cotton fiber. The highest colour yield and chroma values on cotton fiber were observed after process combinations of simultaneous cationizing and mordanting with copper(II) sulphate then dyeing process. Cotton dyeing with Papaver rhoeas exhibited outstanding wash fastness results. Moreover, perspiration and dry rub fastness values were generally in the commercially acceptable range. There is no clear trend that the processes sequence of cationizing, mordanting and dyeing affects the studied colour fastness properties significantly. Cationization increased the inhibitory activity of mordants. Application sequence of cationizing then mordanting then dyeing processes, for each mordant material, resulted in better antibacterial activity leading to higher reduction on $E$. coli. The highest antimicrobial activity ( $72 \%$ reduction) was obtained in the treatment of cationizing then mordanting with copper(II) sulphate then dyeing.
\end{abstract}

Key Words: Papaver rhoeas, Corn poppy, Cationizing, Natural dyeing, Antibacterial properties.

\section{INTRODUCTION}

Cotton is the most preferred natural fiber due to its superior comfort features. Nearly half of the world textile fiber production were occupied by the cellulosic fibers and this amount might rise in the near future because of the environmental concerns ${ }^{1,2}$. Therefore, scientists and producers have been continuously searching for more effective ways of cotton dyeing enabling energy and chemical savings in order to reduce the environmental waste and the production cost. One solution was to increase cotton reactivity by cationizing of cellulose $e^{2,3}$.

Hydroxyl groups of cellulose exhibit negative charge in the presence of water leading to anionic character. However, the most useful dye classes for cotton such as reactive and direct dyes are anionic. In this situation, affinity will decrease and fiber-dye reaction will not be productive. High amount of salt is used to reduce impulsion between cotton and dye. In any case, all dyes are not able to bind to fiber and this result in dye waste and ecological problems ${ }^{4}$. Many chemicals have been invented to improve the interaction between cellulose and dyestuff ${ }^{5}$. It was generally aimed to modify cotton fibers through hydroxyl groups. Etherification, esterification, grafting and cross-linking reactions are extensively used for cationization ${ }^{1}$.

Montazer et. al. ${ }^{4}$ and Mughal et. al. ${ }^{6}$ determined that cationizing process improved the exhaustion and fixation yields leading to higher colour yields and superior fastness properties in reactive dyeing of cotton. Youssef ${ }^{7}$ studied the influence of cationizing on direct dyeing of cotton and stated that cationizing process led to high wet fastness and improved exhaustion and fixation yields. Seong and $\mathrm{Ko}^{8}$ applied 3-chloro2-hydroxypropyltrialkyl derivatives of ammonium chloride to cotton fibers for cationization and it was stated that cationized cotton fibers could be dyed with acid dyes with reported antibacterial properties. Onar ${ }^{9}$ stated that aminization of cotton fabric by an aliphatic polyamine derivative was increased dyeability with direct dyes. 
Natural dyestuffs can be obtained from plants, animals and minerals ${ }^{10,11}$. Mankind has been dyeing fabrics by natural colourants since ancient times and natural dyeing has recently recaptured attention because of its environmental benefits ${ }^{10-15}$. Most of the natural dyestuffs are not able to make bonds with fibers, so mordant chemicals are used to provide affinity between fibers and dyestuffs. Metal salts are suitable as mordant materials. Acidic mordants used for basic dyestuffs and basic mordants are used for acidic dyestuffs ${ }^{16,17}$. Mordanting can be carried out by pre-mordanting, simultaneous mordanting or after mordanting methods ${ }^{18}$.

Papaver rhoeas flowers were used as a natural dye plant in this study. Papaver rhoeas, also known as corn poppy, is an one year plant from papaveraceae family. It grows wildly on very wide and various areas. The plant has dark red flowers and it may reach $90 \mathrm{~cm} \mathrm{high}^{19}$. Papaver rhoeas is shown on Fig. 1.

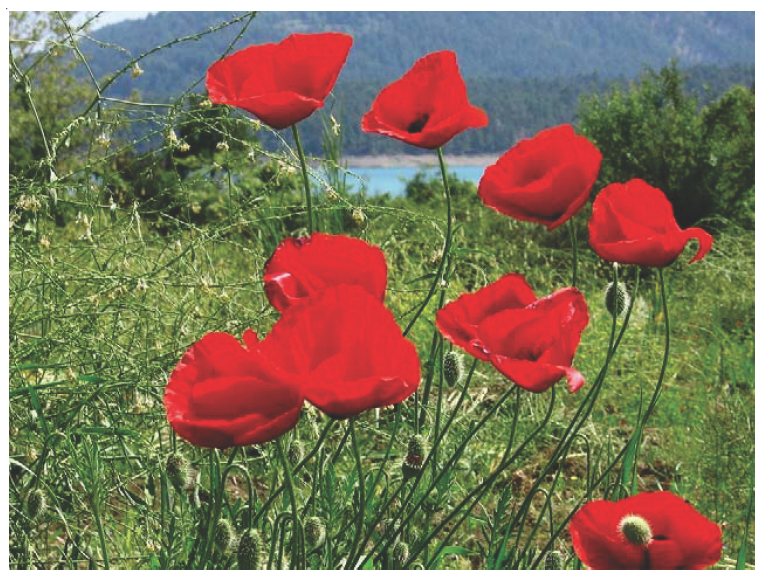

Fig. 1. Corn poppy (Papaver rhoeas) plant [Ref. 20]

Kostic et. al. ${ }^{21}$ reported 9.73-19.91 mg/g total phenolic content in the fresh petals of Papaver rhoeas. In the same study the pigment presented in plant petals is stated as originated from anthocyanines and 4.72-5.19 mg cyanidin-3-O-glucoside content per gram of fresh petals is determined. Furthermore, it is reported that total flavonoid content varies between 7.904 and $11.45 \mathrm{mg} / \mathrm{g}^{21}$. Anthocyanins are members of the flavonoid group of polyphenols. The main part of anthocyanins is its aglycone, the flavylium cation, which contains conjugated double bonds responsible for absorption of light around 500 $\mathrm{nm}$ leading to red appearance to human eye $\mathrm{e}^{22}$.

Anthocyanin pigments have generally been thought to be relatively unstable except in low $\mathrm{pH}$ environments ${ }^{23}$. Metal complexation is one of the factors that affect anthocyanine stability $^{23}$. The most common metals in anthocyanin complexes are tin, copper, iron, aluminum, magnesium and potassium ${ }^{22,23}$. The general structure of Papaver rhoeas anthocyanins is presented in Fig. 2.

Treatments applied to the fabrics for different purposes could develop antimicrobial features which is significant for health issues. In recent years, antimicrobial textiles have gained interest from both academic research and industry because of their potential to provide high quality life and safe benefits to people. Textile products are prone to host microorganisms responsible for diseases, unpleasant odors, colour degradation
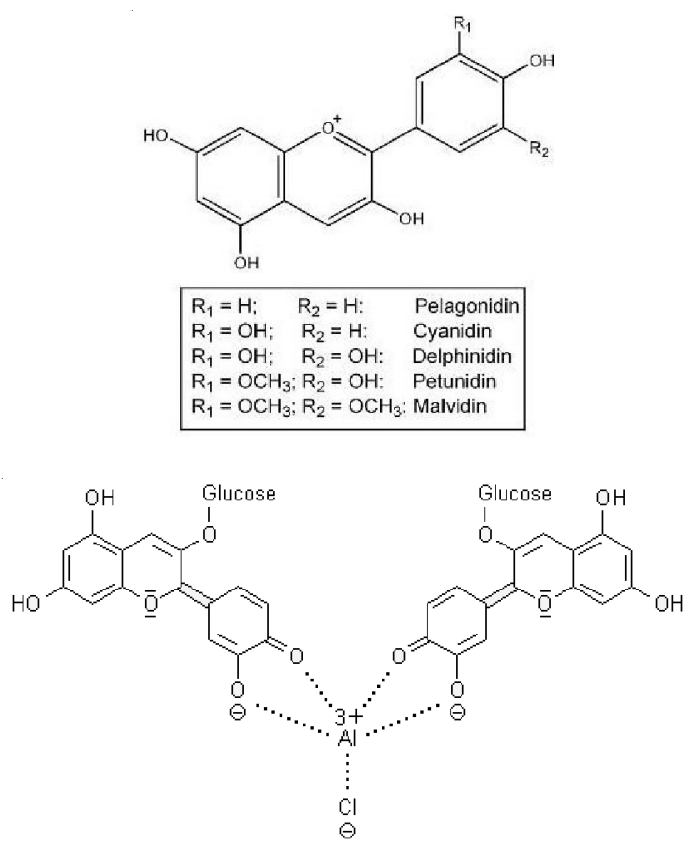

Fig. 2. General structure of Papaver rhoeas anthocyanines and aluminum complex of cyanine-3-glucosides [Ref. 24]

and deterioration of textiles. Self-sterilizing fabrics could have potential benefits to reduce disease transfers among hospital populations, bio warfare protection and other applications. Usually, antimicrobial properties can be acquired to textile materials by chemically or physically incorporating functional agents and natural dyes onto fibers or fabrics. Therefore many studies have been reported for natural dyes and other agents having antimicrobial activity on fabrics ${ }^{25-27}$.

In this study, the general aim was to combine the natural dyeing and cationizing of cotton fibers and to investigate the effect of cationization on colour fastness and colour properties of cotton which is dyed with Papaver rhoeas flowers. The main objective of this research is to increase the dyestuff, which is obtained from limited natural resource, performance leading to improvement on colour fastness and colour yield properties. Cotton fabric was dyed with Papaver rhoeas flowers extract according to eight different processes which are the different combinations of cationizing, mordanting and dyeing. Four different mordant chemicals were applied by pre-mordanting process. Colour properties were determined. Moreover, ISO washing (C06/A2S), alkali and acidic perspiration (E04), wet and dry rub (X12) and light fastness (B02) properties were also examined. The dynamic assessment of antimicrobial activity was carried out according to the standard test method for immobilized antimicrobial agents under dynamic contact (ASTM E2149-01).

\section{EXPERIMENTAL}

Dyestuff Extraction from Papaver rhoeas: Papaver Rhoeas flowers, which are collected from Denizli/Turkey, were used as natural dyestuff source. Flowers were boiled at distilled water for $1 \mathrm{~h}$ in, plant/water (1:40) ratio. Extraction was filtered after boiling and cooled at room temperature. The dyestuff extract was directly used as dyeing liquor accompanied by mordant or cationizing agent. 
Mordanting, dyeing and cationizing processes: $100 \%$ cotton twill woven fabric was used for all applications. Eight different process types (dyeing, dyeing + cationizing, dyeing then cationizing, cationizing then dyeing, mordanting then dyeing, mordanting then dyeing then cationizing, cationizing + mordanting then dyeing, cationizing then mordanting then dyeing) and 4 different mordants (potassium aluminum sulphate, copper(II) sulphate, iron(II) sulphate and tin(II) chloride) were used for dyeing of cotton with Papaver rhoeas flower extract.

Dyeing procedure is shown on Fig. 3. 1:20 liquor ratio was used for each process type; dyeing, mordanting and cationizing procedures. A reactive dyestuff soaping and fixation agent (Laucol RW, Günerca/Turkey) which is based on polyamine derivative was used as a cationizing agent. $4 \%$ owf Laucol RW was applied at pH 5.5 for cationizing procedures. A laboratory type exhaustion dyeing machine was used for all pre-mordanting, cationizing and dyeing processes. Mordant chemicals were applied via pre-mordanting by exhaustion method in a laboratory type dyeing machine. Mordant usage was $4 \%$ owf. Samples were cold rinsed at the end of the process and finally air dried. Mordanting and cationizing procedures are shown on Fig. 4.

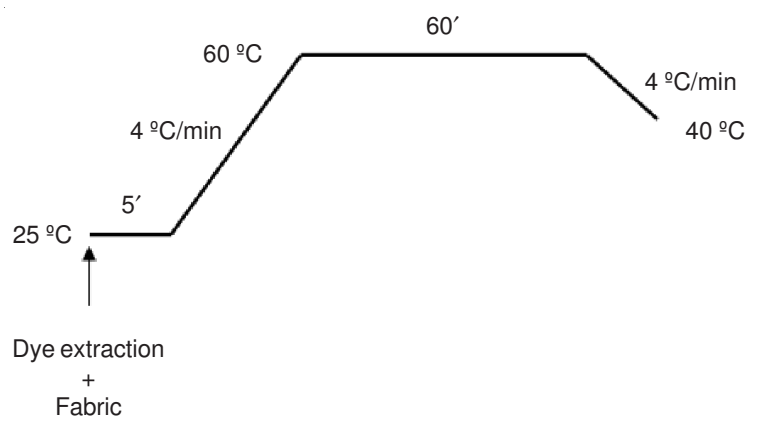

Fig. 3. Dyeing procedure

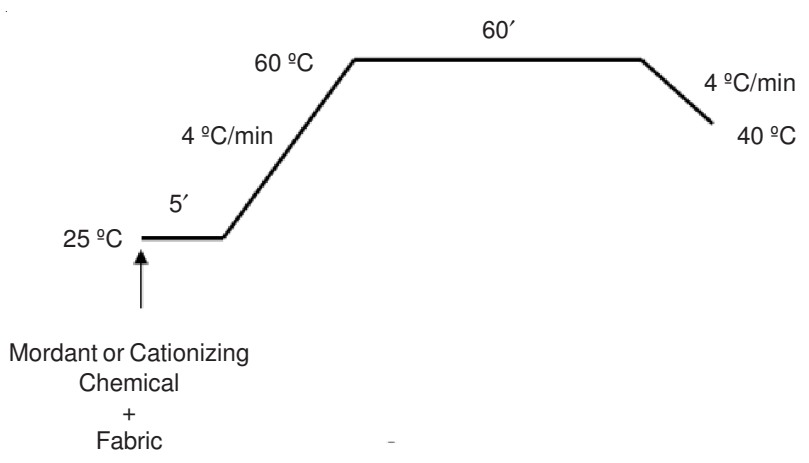

Fig. 4. Mordanting and cationizing procedures

Colour fastness tests: Rub fastness, perspiration fastness, wash fastness and light fastness properties were evaluated. Wash-fastness to domestic laundering (C06) was carried out according to ISO 105:C06 test in a M228 Rotawash machine (SDL ATLAS, UK). The test (C06/A2S) was performed at $40^{\circ} \mathrm{C}$ with sodium perborate. The both alkaline and acid perspiration fastness testing was determined according to the ISO 105-E04 (Colour Fastness to Perspiration) protocol. The both dry and wet rub fastness testing was performed following the ISO 105 :
$\mathrm{X} 12$ protocol. The assessment of colour fastness of the dyed fabrics to washing and to alkaline and acid perspiration (via staining of adjacent cotton and wool in a multifibre strip) and dry and wet rubbing (via staining of cotton rubbing fabric) was carried out using ISO grey scales. Light fastness testing was carried out according to ISO 105: B02: colour fastness to artificial light (Xenon arc lamp). Colour fastness to light was assessed using the blue wool scale.

Colour measurements: After each individual and sequential process, colour properties of cotton fabric dyed with Papaver rhoeas flower were examined. The CIE $L^{*}, a^{*}, b^{*}$, $C^{*}$ and $h^{\circ}$ co-ordinates were measured and the $f(k)$ values calculated from the reflectance values at the appropriate wavelength of maximum absorbance $\left(\lambda_{\max }\right)$ for each dyed samples using a Datacolour 600 spectrophotometer (Datacolour International, Lawrenceville, NJ, USA), spectrophotometer under illuminant $\mathrm{D}_{65}$, using a $10^{\circ}$ standard observer. Each fabric sample was read in four different areas and the average value calculated.

Antibacterial activity: The dynamic assessment of antimicrobial activity was carried out according to the standard test method for immobilized antimicrobial agents under dynamic contact (ASTM E2149-01). Test bacteria (Escherichia coli ATCC25922) were cultured in LB broth (Fluka) overnight inoculations at $37^{\circ} \mathrm{C}$. Subsequently, bacterial culture was dilute in $0.3 \mathrm{mM} \mathrm{KH}_{2} \mathrm{PO}_{4}$ buffer until the solution has an absorbance of $0.28 \pm 0.02$ at $475 \mathrm{~nm}$ as measured spectrophotometrically

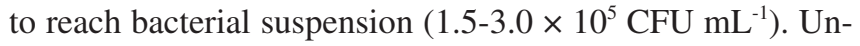
treated and treated cotton fabrics (Table-1) having $4 \mathrm{in}^{2}$ treated surface area were inoculated with $50 \pm 0.5 \mathrm{~mL}$ of bacterial suspension and incubated at $37^{\circ} \mathrm{C} 1 \mathrm{~h} \pm 5 \mathrm{~min}$. Standard plate counts were performed after decimal dilution of the samples in $9 \mathrm{~mL}$ of $0.1 \%$ peptone water; the percent inhibition rate (\%) was calculated as formula of (N1-N2/N1) x 100, where $\mathrm{N} 1$ and $\mathrm{N} 2$ represent the number of colonies on the plates before and after inhibition, respectively. Untreated cotton fabric was used as a negative control where cationized, mordanted and dyed samples separately were used as positive control.

\section{RESULTS AND DISCUSSION}

Colour properties: Colorimetric properties are given at Tables 4 and 5 and Fig. 2(a-c). The potential influence of mordanting process on the colour yield properties of the naturally dyed cotton fabrics will be addressed presently, but it is appropriate first to consider the un-mordanted samples.

Colour yield $(f(k))$ value of sample A (only dyeing without mordant) was the lowest among all samples (Tables 1 and 2). It is assumed that dyestuff in corn poppy dyeing extract can not effectively bond to cotton fiber without the aid of a mordant material. Cationizing increased the colour yield for un-mordanted samples (B and C); however, the sequential process of dyeing then cationizing $(\mathrm{C})$ resulted in very slight colour yield rise by 0.8 . On the other hand, the combination process of dyeing and cationizing (B), at the same time, led to substantial colour yield increase by 9.1 (Tables 1 and 2). Therefore, the colour yield value was increased to11.7 after simultaneous application of cationizing and dyeing (B). It seems that, in the simultaneous process of dyeing and cationizing 


\begin{tabular}{|c|c|c|c|c|}
\hline \multicolumn{5}{|c|}{$\begin{array}{l}\text { TABLE-1 } \\
\text { COLOR YIELDS AND OBTAINED SHADES OF DYED SAMPLES }\end{array}$} \\
\hline $\begin{array}{l}\text { Process } \\
\text { code }\end{array}$ & Process types & Mordant & $f(k)$ & Colors \\
\hline $\mathrm{A}$ & Dyeing & $\begin{array}{l}\text { Without } \\
\text { mordant }\end{array}$ & 2.6 & \\
\hline B & Dyeing + cationizing & $\begin{array}{l}\text { Without } \\
\text { mordant }\end{array}$ & 11.7 & \\
\hline $\mathrm{C}$ & $\begin{array}{l}\text { Dyeing then } \\
\text { cationizing }\end{array}$ & $\begin{array}{l}\text { Without } \\
\text { mordant }\end{array}$ & 3.4 & \\
\hline $\mathrm{D}$ & $\begin{array}{l}\text { Cationizing then } \\
\text { dyeing }\end{array}$ & $\begin{array}{l}\text { Without } \\
\text { mordant }\end{array}$ & 20.7 & \\
\hline E1 & $\begin{array}{l}\text { Mordanting then } \\
\text { dyeing }\end{array}$ & $\begin{array}{l}\text { Potassium } \\
\text { aluminum } \\
\text { sulphate }\end{array}$ & 10.3 & \\
\hline $\mathrm{E} 2$ & $\begin{array}{l}\text { Mordanting then } \\
\text { dyeing }\end{array}$ & $\begin{array}{l}\text { Copper(II) } \\
\text { sulphate }\end{array}$ & 10.2 & \\
\hline E3 & $\begin{array}{l}\text { Mordanting then } \\
\text { dyeing }\end{array}$ & $\begin{array}{l}\text { Tin(II) } \\
\text { chloride }\end{array}$ & 4.6 & \\
\hline $\mathrm{E} 4$ & $\begin{array}{l}\text { Mordanting then } \\
\text { dyeing }\end{array}$ & $\begin{array}{l}\text { Iron(II) } \\
\text { sulphate }\end{array}$ & 9.3 & \\
\hline $\mathrm{F} 1$ & $\begin{array}{l}\text { Mordanting then } \\
\text { dyeing then } \\
\text { cationizing }\end{array}$ & $\begin{array}{l}\text { Potassium } \\
\text { aluminum } \\
\text { sulphate }\end{array}$ & 11.6 & \\
\hline $\mathrm{F} 2$ & $\begin{array}{l}\text { Mordanting then } \\
\text { dyeing then } \\
\text { cationizing }\end{array}$ & $\begin{array}{l}\text { Copper(II) } \\
\text { sulphate }\end{array}$ & 8.7 & \\
\hline F3 & $\begin{array}{l}\text { Mordanting then } \\
\text { dyeing then } \\
\text { cationizing }\end{array}$ & $\begin{array}{l}\text { Tin(II) } \\
\text { chloride }\end{array}$ & 6.8 & \\
\hline $\mathrm{F} 4$ & $\begin{array}{l}\text { Mordanting then } \\
\text { dyeing then } \\
\text { cationizing }\end{array}$ & $\begin{array}{l}\text { Iron(II) } \\
\text { sulphate }\end{array}$ & 13.9 & \\
\hline G1 & $\begin{array}{l}\text { Cationizing + } \\
\text { mordanting then } \\
\text { dyeing }\end{array}$ & $\begin{array}{l}\text { Potassium } \\
\text { aluminum } \\
\text { sulphate }\end{array}$ & 30.1 & \\
\hline G2 & $\begin{array}{l}\text { Cationizing + } \\
\text { mordanting then } \\
\text { dyeing }\end{array}$ & $\begin{array}{l}\text { Copper(II) } \\
\text { sulphate }\end{array}$ & 45.2 & \\
\hline G3 & $\begin{array}{l}\text { Cationizing + } \\
\text { mordanting then } \\
\text { dyeing }\end{array}$ & $\begin{array}{l}\text { Tin(II) } \\
\text { chloride }\end{array}$ & 26.8 & \\
\hline G4 & $\begin{array}{l}\text { Cationizing + } \\
\text { mordanting then } \\
\text { dyeing }\end{array}$ & $\begin{array}{l}\text { Iron(II) } \\
\text { sulphate }\end{array}$ & 41.9 & \\
\hline H1 & $\begin{array}{l}\text { Cationizing then } \\
\text { mordanting then } \\
\text { dyeing }\end{array}$ & $\begin{array}{l}\text { Potassium } \\
\text { aluminum } \\
\text { sulphate }\end{array}$ & 18.0 & \\
\hline $\mathrm{H} 2$ & $\begin{array}{c}\text { Cationizing then } \\
\text { mordanting then } \\
\text { dyeing }\end{array}$ & $\begin{array}{l}\text { Copper(II) } \\
\text { sulphate }\end{array}$ & 27.3 & \\
\hline
\end{tabular}

\begin{tabular}{cccc}
\hline H3 & $\begin{array}{l}\text { Cationizing then } \\
\text { mordanting then } \\
\text { dyeing }\end{array}$ & $\begin{array}{c}\text { Tin(II) } \\
\text { chloride }\end{array}$ & 12.3 \\
H4 & $\begin{array}{l}\text { Cationizing then } \\
\text { mordanting then } \\
\text { dyeing }\end{array}$ & $\begin{array}{c}\text { Iron(II) } \\
\text { sulphate }\end{array}$ & 36.1
\end{tabular}

(B), the usage of catinoization agent creates functional groups on cotton fiber which natural dyestuff can make bonds with. When it comes to sequential application of cationizing then dyeing (D), significantly higher colour yield value was observed by 20.7 in comparison to simultaneous application of cationizing and dyeing (B), 11.7 (Tables 1 and 2). In process $\mathrm{B}$, it is believed that some dyestuffs make complexes, which cannot adequately bind to the cotton fiber, with cationizing agent in the dyeing liquor leading to lower colour yield. However, in process $\mathrm{D}$, formerly applied cationizing agent, which uniformly binds to the cotton fiber, creates more accessible dyeing sites for natural dyestuffs, leading to increased dyestuff-cellulose bonding therefore higher colour yield.

The sequential process of mordanting then dyeing $(\mathrm{E})$ can be considered as the conventional method for pre-mordanting natural dyeing process. All only-mordanted samples (E1-E4) exhibited higher colour yield and darker appearance, according to $f(k)$ and $L^{*}$ values, respectively, in a comparison with that of the only-dyed without a mordant sample (A) (Tables 1 and 2). Similar trend was also observed for the cotton samples which are dyed with the sequential and simultaneous processes of mordanting and cationizing (F1-F4, G1-G4, H1-H4, Tables 1 and 2). It is obvious that mordant material plays an important role for the cotton dyeing with Papaver rhoeas. However, B (dyeing + cationizing) and $\mathrm{D}$ (cationizing then dyeing) prosesses caused higher colour yield values $(f(k))$ than E1-E4 (mordanting then dyeing) processes (Tables 1 and 2). This means that the cationizing agent usage alone, without any mordant usage, resulted in better dyestuff-cellulose bonding effect than the solely usage of mordant material. Therefore, the usage of both cationizing agent and mordant material, in pre-mordanted natural dyeing process, was also investigated in order to see the effect of cationizing agent (F1-F4, G1-G4, H1-H4, Tables 1 and 2).

The positive effect of cationization on colour yield is clearly visible when $\mathrm{G}$ and $\mathrm{H}$ processes are compared with $\mathrm{E}$ process (Table-2). The usage of cationizing agent, which is applied after the pre-mordanted dyeing (F1-F4), did not cause significant colour yield improvement when it is compared with pre-mordanted dyeing processes (E1-E4) (Table-2). However, when the cationizing agent is applied as an initial step before the pre-mordanting and dyeing steps (H1-H4), higher colour yield values were observed in comparison to mordanting then dyeing then cationizing processes (F1-F4). Moreover, when the cationizing agent is applied together with a mordant material at the pre-mordanting step (G1-G4), the highest colour values were obtained. These values were 30.1, 45.2, 26.8 and 41.9 for potassium aluminum sulphate, copper(II) sulphate, tin(II) chloride and iron(II) sulphate, respectively (Table-2). The simultaneous application of cationizing and mordanting resulted in more available dyeing sites for natural dyestuff 


\begin{tabular}{|c|c|c|c|c|c|c|c|c|}
\hline \multicolumn{9}{|c|}{$\begin{array}{c}\text { TABLE-2 } \\
\text { COLORIMETRIC DATA OF DYED SAMPLES }\end{array}$} \\
\hline Process code & Process types & Mordant & $f(k)$ & $L^{*}$ & $a^{*}$ & $b^{*}$ & $C^{*}$ & $h^{o}$ \\
\hline A & Dyeing & Without mordant & 2.6 & 82.8 & 0.2 & 7.7 & 7.7 & 88.7 \\
\hline B & Dyeing + cationizing & Without mordant & 11.7 & 67.0 & -4.6 & 9.3 & 10.4 & 116.4 \\
\hline $\mathrm{C}$ & Dyeing then cationizing & Without mordant & 3.4 & 80.1 & -1.7 & 6.0 & 6.2 & 105.7 \\
\hline $\mathrm{D}$ & Cationizing then dyeing & Without mordant & 20.7 & 59.0 & -0.3 & 10.6 & 10.6 & 91.6 \\
\hline E1 & Mordanting then dyeing & Potassium aluminum sulphate & 10.3 & 70.6 & -6.5 & 14.6 & 15.9 & 114.0 \\
\hline E2 & Mordanting then dyeing & Copper(II) sulphate & 10.2 & 73.8 & -4.1 & 25.1 & 25.4 & 99.2 \\
\hline E3 & Mordanting then dyeing & Tin(II) chloride & 4.6 & 77.6 & -0.8 & 6.9 & 7.0 & 96.3 \\
\hline E4 & Mordanting then dyeing & Iron(II) sulphate & 9.3 & 71.8 & 1.9 & 16.6 & 16.7 & 83.4 \\
\hline $\mathrm{F} 1$ & Mordanting then dyeing then cationizing & Potassium aluminum sulphate & 11.6 & 70.5 & -7.0 & 19.5 & 20.7 & 109.9 \\
\hline $\mathrm{F} 2$ & Mordanting then dyeing then cationizing & Copper(II) sulphate & 8.7 & 74.2 & -2.7 & 21.5 & 21.7 & 97.3 \\
\hline F3 & Mordanting then dyeing then cationizing & Tin(II) chloride & 6.8 & 74.9 & -2.6 & 12.0 & 12.3 & 102.4 \\
\hline $\mathrm{F} 4$ & Mordanting then dyeing then cationizing & Iron(II) sulphate & 13.9 & 66.8 & 2.4 & 17.7 & 17.9 & 82.2 \\
\hline G1 & Cationizing + mordanting then dyeing & Potassium aluminum sulphate & 30.1 & 57.6 & -8.1 & 20.9 & 22.5 & 111.2 \\
\hline G2 & Cationizing + mordanting then dyeing & Copper(II) sulphate & 45.2 & 53.2 & -3.6 & 26.8 & 27.0 & 97.7 \\
\hline G3 & Cationizing + mordanting then dyeing & Tin(II) chloride & 26.8 & 55.4 & -1.9 & 8.3 & 8.5 & 103.1 \\
\hline G4 & Cationizing + mordanting then dyeing & Iron(II) Sulphate & 41.9 & 48.5 & -0.7 & 10.7 & 10.7 & 93.7 \\
\hline $\mathrm{H} 1$ & Cationizing then mordanting then dyeing & Potassium Aluminum sulphate & 18.0 & 66.1 & -5.8 & 24.0 & 24.7 & 103.6 \\
\hline $\mathrm{H} 2$ & Cationizing then mordanting then dyeing & Copper(II) sulphate & 27.3 & 60.2 & -2.2 & 25.8 & 25.9 & 95.0 \\
\hline $\mathrm{H} 3$ & Cationizing then mordanting then dyeing & Tin(II) chloride & 12.3 & 67.8 & -1.8 & 12.5 & 12.7 & 98.2 \\
\hline $\mathrm{H} 4$ & Cationizing then mordanting then dyeing & Iron(II) sulphate & 36.1 & 51.7 & 1.6 & 14.0 & 14.1 & 83.4 \\
\hline
\end{tabular}

TABLE-3

PERSPIRATION FASTNESS VALUES

\begin{tabular}{|c|c|c|c|c|c|c|}
\hline \multirow{3}{*}{$\begin{array}{c}\text { Process } \\
\text { code }\end{array}$} & \multirow{3}{*}{ Process types } & \multirow{3}{*}{ Mordant } & \multicolumn{4}{|c|}{ Perspiration fastness (E04)(staining on cotton and wool) } \\
\hline & & & \multicolumn{2}{|c|}{ Acidic } & \multicolumn{2}{|c|}{ Alkaline } \\
\hline & & & Cotton & Wool & Cotton & Wool \\
\hline A & Dyeing & Without mordant & 5 & 5 & 5 & 5 \\
\hline B & Dyeing + cationizing & Without mordant & $4 / 5-5$ & $4 / 5-5$ & $4 / 5$ & $4 / 5$ \\
\hline $\mathrm{C}$ & Dyeing then cationizing & Without mordant & 5 & 5 & 5 & 5 \\
\hline $\mathrm{D}$ & Cationizing then dyeing & Without mordant & $4 / 5-5$ & 5 & 5 & 5 \\
\hline E1 & Mordanting then dyeing & Potassium aluminum sulphate & $4 / 5$ & 5 & $4 / 5-5$ & 5 \\
\hline E2 & Mordanting then dyeing & Copper(II) sulphate & $4 / 5$ & $4 / 5$ & $4-4 / 5$ & $4 / 5$ \\
\hline E3 & Mordanting then dyeing & Tin(II) chloride & 5 & 5 & 5 & 5 \\
\hline $\mathrm{E} 4$ & Mordanting then dyeing & Iron(II) sulphate & $4 / 5-5$ & 5 & 5 & 5 \\
\hline $\mathrm{F} 1$ & Mordanting then dyeing then cationizing & Potassium aluminum sulphate & 5 & 5 & 5 & 5 \\
\hline $\mathrm{F} 2$ & Mordanting then dyeing then cationizing & Copper(II) sulphate & $4 / 5-5$ & $4 / 5$ & $4 / 5$ & $4 / 5$ \\
\hline F3 & Mordanting then dyeing then cationizing & Tin(II) chloride & 5 & 5 & 5 & 5 \\
\hline $\mathrm{F} 4$ & Mordanting then dyeing then cationizing & Iron(II) sulphate & 5 & 5 & 5 & 5 \\
\hline G1 & Cationizing + mordanting then dyeing & Potassium aluminum sulphate & $4 / 5-5$ & 5 & 5 & 5 \\
\hline G2 & Cationizing + mordanting then dyeing & Copper(II) sulphate & $4-4 / 5$ & $4 / 5$ & $3-3 / 4$ & $4-4 / 5$ \\
\hline G3 & Cationizing + mordanting then dyeing & Tin(II) chloride & 5 & 5 & 5 & 5 \\
\hline G4 & Cationizing + mordanting then dyeing & Iron(II) sulphate & 5 & 5 & 5 & 5 \\
\hline $\mathrm{H} 1$ & Cationizing then mordanting then dyeing & Potassium aluminum sulphate & $4 / 5-5$ & 5 & 5 & 5 \\
\hline $\mathrm{H} 2$ & Cationizing then mordanting then dyeing & Copper(II) sulphate & 4 & $4 / 5$ & $3 / 4-4$ & $4 / 5$ \\
\hline $\mathrm{H} 3$ & Cationizing then mordanting then dyeing & Tin(II) chloride & 5 & 5 & 5 & 5 \\
\hline $\mathrm{H} 4$ & Cationizing then mordanting then dyeing & Iron(II) sulphate & 5 & 5 & 5 & 5 \\
\hline
\end{tabular}

attraction. So, the cationizing agent should be applied as a first step, not after dyeing, by either simultaneous application of pre-mordanting and cationizing or sequential application of cationizing then pre-mordanting.

The colorimetric changes imparted to each dyeings by different cominations of mordanting, cationizing and dyeing are clearly more visible in $a^{*} v s . b^{*}, C^{*} v s . f(k)$ and $C^{*} v s . L^{*}$ plots shown in Fig. 5(a-c). Different shades of green, brown, lead and tan colours were obtained (Table-1). The differences of these visual appearances were also detected on $a^{*}, b^{*}$ and $h^{\circ}$ values [Fig. 5(a) and Table-2]. From Fig. 5(a), it is clearly seen that different mordants resulted in different shades. Dyed samples became in groups according to the respective mordant matter in $a^{*}$ (greenness-redness) vs. $b^{*}$ (yellowness-blueness) plot. It means that approximately similar shades were obtained with same mordant usage in different processes [Fig. 5(a)]. For instance, different shades of green colours were occurred with the usage of copper(II) sulphate mordant [red points in $a^{*}$ vs. $b^{*}$ plot, Fig. 5(a)].

The highest colour yield by 45.2 and chroma by 27.0 were observed in cationizing + mordanting then dyeing process with the copper(II) sulphate mordant usage [G2, Fig. 5(b)]. Overall, the usage of tin(II) chloride mordant exhibited the lowest colour yield and chroma values among the usage of all other mordants when it was compared among the same respective process types. Copper(II) sulphate resulted the highest chroma values [red points in $C^{*} v s . f(k)$ plot, Fig. 5(b)]. It is important to note that, from $C^{*} v s . f(k)$ plot in Fig. $5(\mathrm{~b})$, the process 


\begin{tabular}{|c|c|c|c|c|c|}
\hline \multicolumn{6}{|c|}{$\begin{array}{c}\text { TABLE-4 } \\
\text { RUB FASTNESS VALUES }\end{array}$} \\
\hline \multirow{2}{*}{$\begin{array}{c}\text { Process } \\
\text { code }\end{array}$} & \multirow{2}{*}{ Process types } & \multirow{2}{*}{ Mordant } & \multirow{2}{*}{$\mathrm{f}(\mathrm{k})$} & \multicolumn{2}{|c|}{ Rub fastness (X12) (cotton staining) } \\
\hline & & & & Dry & Wet \\
\hline A & Dyeing & Without mordant & 2.6 & 5 & $4 / 5$ \\
\hline B & Dyeing + cationizing & Without mordant & 11.7 & $4 / 5$ & 4 \\
\hline $\mathrm{C}$ & Dyeing then cationizing & Without mordant & 3.4 & 5 & $4 / 5$ \\
\hline $\mathrm{D}$ & Cationizing then dyeing & Without mordant & 20.7 & 5 & $4-4 / 5$ \\
\hline E1 & Mordanting then dyeing & Potassium aluminum sulphate & 10.3 & 5 & $4 / 5$ \\
\hline E2 & Mordanting then dyeing & Copper(II) sulphate & 10.2 & 5 & $4 / 5$ \\
\hline E3 & Mordanting then dyeing & Tin(II) chloride & 4.6 & 5 & $4 / 5$ \\
\hline $\mathrm{E} 4$ & Mordanting then dyeing & Iron(II) sulphate & 9.3 & 4 & $3 / 4$ \\
\hline $\mathrm{F} 1$ & Mordanting then dyeing then cationizing & Potassium aluminum sulphate & 11.6 & $4 / 5-5$ & $4-4 / 5$ \\
\hline $\mathrm{F} 2$ & Mordanting then dyeing then cationizing & Copper(II) sulphate & 8.7 & 5 & 4 \\
\hline F3 & Mordanting then dyeing then cationizing & Tin(II) chloride & 6.8 & 5 & $4 / 5$ \\
\hline $\mathrm{F} 4$ & Mordanting then dyeing then cationizing & Iron(II) sulphate & 13.9 & 4 & $3-3 / 4$ \\
\hline G1 & Cationizing + mordanting then dyeing & Potassium aluminum sulphate & 30.1 & $4 / 5$ & $2 / 3-3$ \\
\hline G2 & Cationizing + mordanting then dyeing & Copper(II) sulphate & 45.2 & $4 / 5-5$ & $2 / 3-3$ \\
\hline G3 & Cationizing + mordanting then dyeing & Tin(II) chloride & 26.8 & $4 / 5$ & 4 \\
\hline G4 & Cationizing + mordanting then dyeing & Iron(II) sulphate & 41.9 & 5 & $3 / 4-4$ \\
\hline H1 & Cationizing then mordanting then dyeing & Potassium aluminum sulphate & 18.0 & $3 / 4-4$ & $4 / 5-5$ \\
\hline $\mathrm{H} 2$ & Cationizing then mordanting then dyeing & Copper(II) sulphate & 27.3 & 5 & 4 \\
\hline $\mathrm{H} 3$ & Cationizing then mordanting then dyeing & Tin(II) chloride & 12.3 & $4 / 5$ & 4 \\
\hline $\mathrm{H} 4$ & Cationizing then mordanting then dyeing & Iron(II) sulphate & 36.1 & 4 & 3 \\
\hline
\end{tabular}

types are more important than the type of mordant material for achieving higher colour yield $[f(k)]$. It is known that colour brightness rises while $C^{*}$ and $L^{*}$ values are both rizing at the same time ${ }^{28}$. The usage of potassium aluminum sulphate and copper(II) sulphate mordants generally led to brighter appearance than the usage of other two mordants studied [red and black points in $C^{*} v s . L^{*}$ plot, Fig. 5(c)].

Colour fastness properties: Measured values of the various fastness indicators for cotton fabrics dyed with the extract of Papaver rhoeas flowers with different application orders of mordanting, cationizing and dyeing in company with different mordant materials are shown in Tables 3-5.

Wash fastness: Wash fastness values were very good, with gray scale rating of 5 , for all samples for each fiber on the multifiber. Cotton dyeing with Papaver rhoeas exhibited excellent results for wash fastness.

Perspiration fastness: Acidic and alkaline perspiration fastness properties of dyed cotton fabrics are shown in Table-3. Adequate perspiration fastness values were obtained on dyeing of cotton with Papaver rhoeas.

Only wool and cotton fiber components, in the multifiber adjacent fabric, were stained. However, the perspiration fastness values are in the commercially acceptable range. The observed fastness values were either 4 or above with only two exceptions. Overall, copper(II) sulphate mordant resulted in slightly lower perspiration fastness values than other mordants studied. Only the alkaline perspiration fastness values of $\mathrm{G} 2$ and $\mathrm{H} 2$ samples were below 4 by 3-3/4 and 3/4-4, respectively, but only for

TABLE-5

LIGHT FASTNESS VALUES

\begin{tabular}{cllcc}
\hline Process code & \multicolumn{1}{c}{ Process types } & \multicolumn{1}{c}{ Mordant } & $f(k)$ & Light fastness (Xenon)(1-8) \\
\hline A & Dyeing & Without mordant & 2.6 & 1.5 \\
B & Dyeing + cationizing & Without mordant & 11.7 & 1.5 \\
C & Dyeing then cationizing & Without mordant & 3.4 & 1 \\
D & Cationizing then dyeing & Without mordant & 20.7 & 1.5 \\
E1 & Mordanting then dyeing & Potassium aluminum sulphate & 10.3 & 1 \\
E2 & Mordanting then dyeing & Copper(II) sulphate & 10.2 & 2.5 \\
E3 & Mordanting then dyeing & Tin(II) chloride & 4.6 & 1 \\
E4 & Mordanting then dyeing & Iron(II) sulphate & 9.3 & 3 \\
F1 & Mordanting then dyeing then cationizing & Potassium aluminum sulphate & 11.6 & 1 \\
F2 & Mordanting then dyeing then cationizing & Copper(II) sulphate & 8.7 & 3 \\
F3 & Mordanting then dyeing then cationizing & Tin(II) chloride & 6.8 & 1 \\
F4 & Mordanting then dyeing then cationizing & Iron(II) sulphate & 13.9 & 3 \\
G1 & Cationizing + mordanting then dyeing & Potassium aluminum sulphate & 30.1 & 45.2 \\
G2 & Cationizing + mordanting then dyeing & Copper(II) sulphate & 26.8 & 1 \\
G3 & Cationizing + mordanting then dyeing & Tin(II) chloride & 41.9 & 3 \\
G4 & Cationizing + mordanting then dyeing & Iron(II) sulphate & 18.0 & 1.5 \\
H1 & Cationizing then mordanting then dyeing & Potassium aluminum sulphate & 27.3 & 3 \\
H2 & Cationizing then mordanting then dyeing & Copper(II) sulphate & 12.3 & 1 \\
H3 & Cationizing then mordanting then dyeing & Tin(II) chloride & 36.1 & 2 \\
H4 & Cationizing then mordanting then dyeing & Iron(II) sulphate & & 1 \\
\hline
\end{tabular}



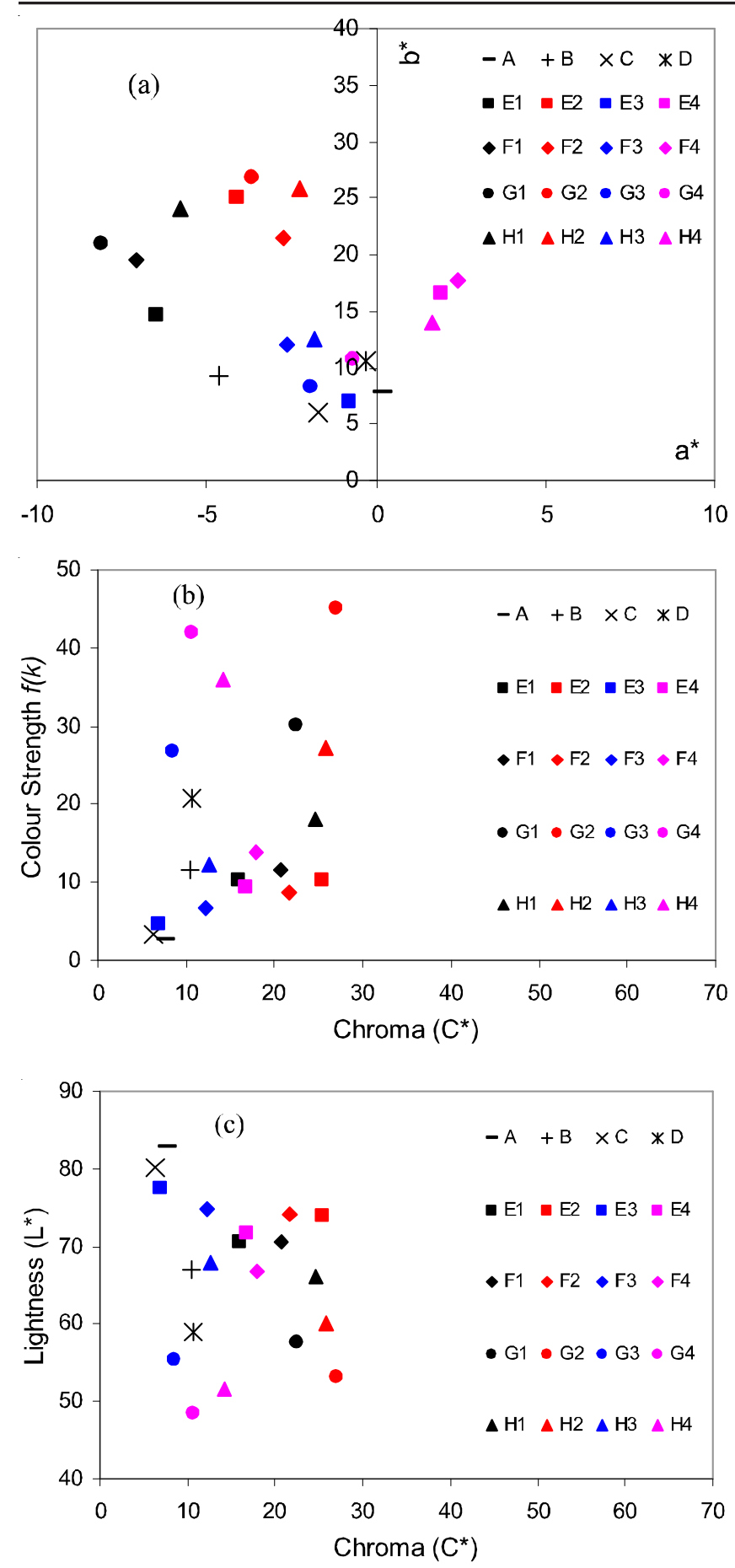

Fig. 5. Color properties of samples dyed with papever rhoeas: (a) $a^{*} v s$. $b^{*},(\mathrm{~b}) C^{*} v s . f(k)$ (c) $C^{*} v s . L^{*}$ plots

the cotton component. Copper(II) sulphate mordanted cotton samples with higher $f(k)$ values $(\mathrm{G} 2, \mathrm{H} 2$, Table-5), therefore higher amount of dyestuff bonding to fiber, exhibited lower alkali perspiration fastness results.

There is no significant effect of different application process orders of mordanting, cationizing and dyeing on perspiration fastness properties.

Rub fastness: Dry and wet rub fastness properties of dyed cotton fabrics are shown in Table-4. Dry rub fastness values of Papaver rhoeas flower dyed samples were generally in the commercially acceptable range. Only sample H1 (cationizing then mordanting then dyeing process accompanied with potassium aluminum sulphate mordant) exhibited slightly lower fastness values than 4 by 3/4-4. Wet rub fastness values were up to 2 points lower than the corresponding values of dry rub fastness. However, it should not be forgotten that only cold rinsing were applied to the all dyed samples after dyeing. Wet rub fastness properties may be improved with more aggressive washing after dyeing.

Samples mordanted with tin(II) chloride (E3, F3, G3, H3) exhibited commercially acceptable wet and dry rub fastness levels (Table-4). Moreover, the usage of copper(II) sulphate as mordant material for dyeing cotton with Papaver rhoeas flower also exhibited commercially acceptable wet and dry rub fastness levels with one exception. The utilization of copper(II) sulphate with cationizing + mordanting then dyeing process $(\mathrm{G} 2$,) resulted in low wet rub fastness by $2 / 3-3$. Iron(II) sulphate generally exhibited slightly lower rub fastness values than other mordants studied.

There is no clear trend regarding any positive or negative effects of the process sequence of cationizing, mordanting and dyeing on the rub fastness properties of cotton fiber dyed with Papaver rhoeas flower. In general, but not a rule, the samples having stronger colour yield, by $\mathrm{f}(\mathrm{k})$, exhibited slightly worse rub fastness results.

Light fastness: Light fastness values are given in Table5. The light fastness value of only-dyed sample, without any other auxiliaries' involvement (A), was 1.5. The light fastness values of un-mordanted were not satisfying. Even the cationizing alone, without any mordant material application, did not cause an adequate improvement on light fastness properties (B, C, $\mathrm{D}$, Table-5). Moreover, potassium aluminum sulphate and tin(II) chloride mordants resulted in very low light fastness values, in the range of 1.0-1.5 points, for all cationizing and mordanting combinations.

The highest light fastness values of 3 for all processes are obtained on iron(II) sulphate mordanted samples (E4, F4, G4, $\mathrm{H} 4$,). Generally, cationizing caused neither significant improvement nor considerable deterioration (up to 0.5 point difference in some cases) on light fastness properties when $\mathrm{F}$, $\mathrm{G}$ and $\mathrm{H}$ processes are compared with $\mathrm{E}$ (mordanting then dyeing). Furthermore, the process sequence of cationizing, mordanting and dyeing. There is no distinct trend that the process sequence of cationizing, mordanting and dyeing affects the light fastness properties of cotton fiber, dyed with Papaver rhoeas flower, significantly.

Antibacterial activity: At the antibacterial activity trials, higher inhibitory activity at cotton fabrics was achieved in case of using cationizing, mordanting and dyeing process together than using separately (Fig. 6).

Antibacterial analysis indicated that separate cationizing and dyeing, simultaneous dyeing and cationizing (process B) had not any significant inhibitory effect on E. coli. Also, $5 \%$ reduction for dyeing then cationizing (C process) and $22 \%$ reduction for cationizing then dyeing (D process) were observed. However, mordants (potassium aluminum sulphate, copper(II) sulphate and tin(II) chloride) were found to be the main responsible for relevant antibacterial activity on $E$. coli. Among the used mordants, copper(II) sulphate (solely mordanted sample) yielded highest reduction at E. coli with $40 \%$. Similarly, earlier studies also reported these mordants 


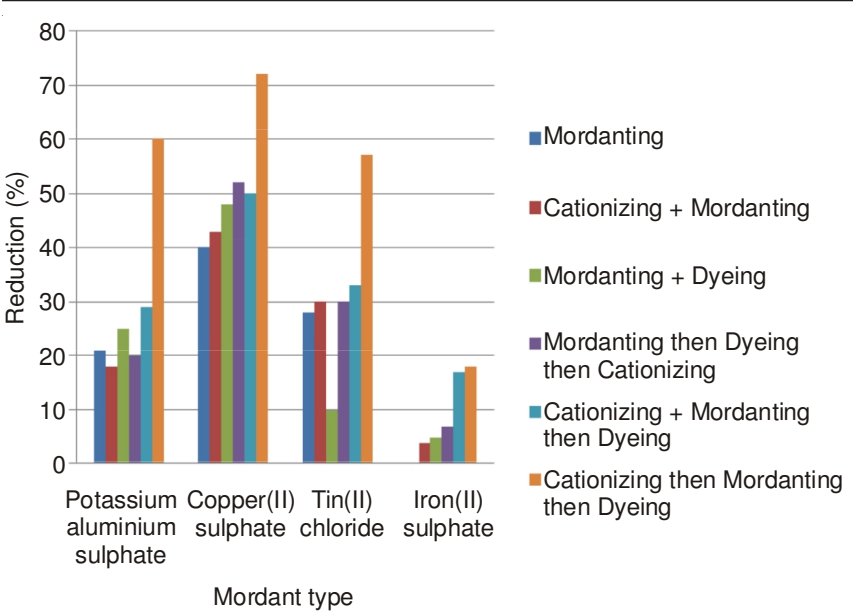

Fig. 6. Relative antibacterial activity of cotton fabrics depending on mordant and process type. Antibacterial activity was shown as the reduction percentage of initial E. coli ATCC25922 count

as having antimicrobial activity when incorporated in fabrics ${ }^{27,29-31}$. The inhibitory mechanism of mordants is attributed to the leaching activity which resulted disruption of membrane integrity and caused leakage of cytoplasm and loss of ATP.

On the other hand, natural dyes could inhibit microorganisms when incorporated with fabrics. In present study, cotton fibers, dyed with Papaver rhoeas flower, did not showed any significant inhibitory activity. No inhibitory activity of Papaver rhoeas extract was also reported by Middleton et al. ${ }^{32}$. However, inhibitory activity slightly increased when used together with mordanting. This is possibly due to the high phenolic composition of Papaver rhoeas flower extracts ${ }^{21}$ which may interact with mordant complexes especially copper(II) sulphate and increased its concentration on the fibers. In fact this was also supported by the shading results which have higher intensity.

The other interesting result obtained by antibacterial results was that cationization increased the inhibitory activity of mordants. Especially, in the application of cationizing then mordanting yielded higher reductions on E. coli. In this respect, the highest antimicrobial activity ( $72 \%$ reduction) was obtained in the treatment of cationizing then mordanting with copper(II) sulphate then dyeing. This relative increase at antibacterial activity might be attributed to the high level binding capacity of mordants after cationizing. On the other side, inhibitory activity might be increased with the dye increase. Although significant inhibitory effect could not be detected when Papaver rhoeas flower extracts were used in the well diffusion assay (data not shown), the relevant cationizing processes could concentrate the dye on the fiber more than used in wells $s$ o that antibacterial activity might be developed as dose dependent.

\section{Conclusion}

Different shades of green, brown, lead and tan colours were obtained on cotton fiber dyed with Papaver rhoeas flowers. The dyeing application of Papaver rhoeas flowers alone, without mordanting and cationizing, resulted in very low colour yield. On the other hand, cationizing process increased the colour yield on both un-mordanted and mordanted samples. Sequential application of cationizing then dyeing resulted in significantly higher colour yield value than simultaneous application of cationizing and dyeing. Mordant material plays an important role for the cotton dyeing with Papaver rhoeas. However, the cationizing agent usage alone prior to dyeing, without any mordant usage, resulted in better dyestuff-cellulose bonding effect than the solely usage of mordant material. The application of a cationizing agent together with a mordant material at the pre-mordanting step then dyeing caused the highest colour values on cotton fiber. The cationizing agent should be applied as a first step, not after dyeing, by either simultaneous application of pre-mordanting and cationizing or sequential application of cationizing then pre-mordanting. The highest colour yield and chroma values on cotton fiber were observed after process combinations of simultaneous cationizing and mordanting with copper(II) sulphate then dyeing process. The usage of tin(II) chloride mordant exhibited the lowest colour yield and chroma values. The process types are more important than the type of mordant material for achieving higher colour yield. The usage of potassium aluminum sulphate and copper(II) sulphate mordants usage generally led to brighter appearance.

Cotton dyeing with Papaver rhoeas exhibited excellent results for wash fastness. In general, perspiration fastness values were in the commercially acceptable range. Copper(II) sulphate mordant resulted in slightly lower perspiration fastness values than other mordants studied. There is no significant effect of different application process orders of mordanting, cationizing and dyeing on perspiration fastness properties.

Dry rub fastness values of Papaver rhoeas flower dyed samples were generally in the commercially acceptable range. Wet rub fastness values were up to 2 points lower than the corresponding values of dry rub fastness. The usage of tin(II) chloride mordant resulted commercially acceptable wet and dry rub fastness values. There is no clear trend regarding any positive or negative effects of the process order of cationizing, mordanting and dyeing on the rub fastness properties.

The light fastness values of un-mordanted samples and the samples mordanted with potassium aluminum sulphate and tin(II) chloride mordants, for all different process combinations, were not satisfactory. The highest light fastness values of 3 for all processes are obtained on iron(II) sulphate mordanted samples. Cationizing process generally caused neither significant improvement nor considerable deterioration on light fastness properties. There is no distinct trend that the processes sequence of cationizing, mordanting and dyeing affects the light fastness properties significantly.

No antibacterial effect was detected for Papaver rhoeas extract. The main factor of the antibacterial activity for $E$. coli. is thought to be the usage of mordants (potassium aluminum sulphate, copper(II) sulphate and tin(II) chloride). However, inhibitory activity slightly increased when mordanting and dyeing applied together. The cationization increased the inhibitory activity of mordants. The highest antimicrobial activity was obtained in the treatment of cationizing then mordanting with copper(II) sulphate then dyeing. Best results were observed for cationizing then mordanting then dyeing processes for each mordant material. 


\section{REFERENCES}

1. H. Wang and D.M. Lewis, Coloration Technol., 118, 159 (2002).

2. M.M. Hashem, Coloration Technol., 122, 135 (2006).

3. D.M. Lewis and K.A. McIlroy, Rev. Prog. Coloration, 27, 5 (1997).

4. M. Montazer, R.M.A. Malek and A. Rahimi, Fibers Polym., 8, 608 (2007).

5. M. Shahid, Shahid-ul-Islam and F. Mohammad, J. Cleaner Prod., 53, 310 (2013).

6. M.J. Mughal, M. Naeem, A. Aleem, R. Saeed and K. Ahmed, Coloration Technol., 124, 62 (2008).

7. Y.A. Youssef, J. Soc. Dyes Color, 116, 316 (2000).

8. H.S. Seong and S.W. Ko, J. Soc. Dyes Color., 114, 124 (1998).

9. N. Onar, J. Textiles Eng., 61, 33 (2006).

10. R. Räisänen, Anthraquinones from the Fungus Dermocybe sanguinea as Textile Dyes. Academic Dissertation, University of Helsinki (2002).

11. A.K. Samanta, P. Agarwal, D. Singhee and S. Datta, J. Textile Inst., 100, 565 (2009).

12. A.K. Samanta and P. Agarwal, Indian J. Fiber Textile Res., 34, 384 (2009).

13. P. Nilani, B. Duraisami, P. Dhamodaran, N. Kasthuribai, A. Semwol and B. Suresh, J. Pharm. Res., 1, 175 (2008).

14. R. Räisänen, P. Nousiainen and P.H. Hynninen, Textile Res. J., 71, 1016 (2001).

15. R. Mongkholrattanasit, J. Kryštùfek, J. Wiener and M. Vikova, Fibres Textiles Eastern Eur., 19, 94 (2011).

16. M. Bebekli, M.Sc. Thesis, Dogal Kaynaklardan Boyarmadde Izolesi ve Pratikte Kullanilabilirliginin Incelenmesi. Çukurova University Institute of Basic and Applied Sciences, Adana (1998).

17. I. Özturk, Dogal Bitkisel Boyalarla Yün Boyama, Dokuz Eylul Publications (1999).
18. P. Nilani, B. Duraisamy, P. Dhamodaran, N. Kasthuribai, A. Semwol and B. Suresh, J. Pharm. Res., 1, 175 (2008).

19. S.S. Isbilir, Ph.D. Thesis, Yapraklari Salata-Baharat Olarak Tüketilen Bazi Bitkilerin Antioksidan Aktivitelerinin Ýncelenmesi, Trakya University Institute of Natural Scieces, Edirne (2008).

20. http://imageshack.us/photo/my-images/220/1186946vn0.jpg/sr=1; accessed on June (2011).

21. D.A. Kostic, S.S. Mitic, M.N. Mitic, A.R. Zarubica, J.L. Velickovic, A.S. Dordevic and S.S. Randelovic, J. Med. Plants Res., 4, 1727 (2010).

22. M. Rein, Copigmentation Reactions and Color Stability of Berry Anthocyanins, Academic Dissertation, University of Helsinki Department of Applied Chemistry and Microbiology Food Chemistry Division (2005).

23. T. Bechtold and R. Mussak, Handbook of Natural Colorants, John Wiley \& Sons, Ltd. (2009).

24. N. Merdan, K. Acar and B. Korkmaz, Istanbul Ticaret Üniversitesi Fen Bilimleri Dergisi, 19, 89 (2011).

25. K. Erdem and Y. Sanli, IUFS J. Biol., 67, 115 (2008).

26. M.I. Khan, A. Ahmad, S.A. Khan, M. Yusuf, M. Shahid, N. Manzoor and F. Mohammad, J. Cleaner Prod., 19, 1385 (2011).

27. M. Yusuf, A. Ahmad, M. Shahid, M.I. Khan, S.A. Khan, N. Manzoor and F. Mohammad, J. Cleaner Prod., 27, 42 (2012).

28. R.S. Berns, Billmeyer and Saltzman's Principles of Color Technology, John Wiley and Sons, edn. 3 (2000).

29. R. Singh, A. Jain, S. Panwar, D. Gupta and S.K. Khare, Dyes Pigm., 66, 99 (2005).

30. D. Gupta, S.K. Khare and A. Laha, Color. Technol., 120, 167 (2004).

31. D. Gupta and A. Laha, Indian J. Fibre Textile Res., 32, 88 (2007).

32. P. Middleton, F. Stewart, S. Al-Qahtani, P. Egan, C. O'Rourke, A. Abdulrahman, M. Byres, M. Middleton, Y. Kumarasamy, L. Shoebm, Nahar, A. Delazar and S.D. Sarker, Iran. J. Pharm. Res., 2, 81 (2005). 